\title{
Assessment of Solubility, Heavy Metals and Microbial Safety in Differently-Treated Muscle Tissues of Mackerel Scomber japonicus
}

\author{
A. K. M. Asaduzzaman ${ }^{1}$, Won-Kyoung Lee ${ }^{2}$ and Byung-Soo Chun ${ }^{1 *}$ \\ ${ }^{1}$ Department of Food Science and Technology, Pukyong National University, 45 Yongso-ro, Nam-Gu, Busan 608-737, \\ Republic of Korea. \\ ${ }^{2}$ Dongwonhaesarang, 24, Gamcheonhang-ro, Saha-gu, Busan, Korea
}

\begin{abstract}
We measured the reductions in size and solubility of mackerel muscle that was freeze-dried, deoiled by supercritical carbon dioxide $\left(\mathrm{SC}-\mathrm{CO}_{2}\right)$, or roasted. The percent size reduction and solubility were high in $\mathrm{SC}-\mathrm{CO}_{2}$-treated muscle compared with freeze-dried and roasted muscle. We used oil-free residues to test for heavy metals and determine microbial safety. The $\mathrm{SC}-\mathrm{CO}_{2}$, hexane, and ethanol were used to separate oil from muscle. The concentrations of cadmium $(\mathrm{Cd})$ in all treated muscles were less than the values reported in the literature, as were the concentrations of lead in $\mathrm{SC}-\mathrm{CO}_{2}$ - and hexane- treated muscle. In contrast, concentrations of arsenic and mercury in muscles were greater than the reported values regardless of treatment. Zinc and iron, which are beneficial for health, were found in high levels after all treatments of muscle tissue. After 6 months of storage at different temperatures, SC$\mathrm{CO}_{2}$ - and ethanol-treated muscle showed few bacterial colonies, and none were found after 4 months of storage at $-20^{\circ} \mathrm{C}$. These results will be useful to food-processing industries for maintaining high-quality, safe mackerel muscle.
\end{abstract}

Key words: Heavy metals, Mackerel muscle, Microbial safety, Size reduction, Solubility

\section{Introduction}

Size reduction (sieving) is the method by which solid pieces of food are reduced in size by grinding, compression, or impact. When force is applied to a food the resulting internal strains are first absorbed and cause deformation of the tissues. If the strain does not exceed a critical level, the tissues return to their original shape when the stress is removed, and the stored energy is released as heat. Size reduction is used to control the textural or rheological properties of foods, and improves the efficiency of mixing, extraction, and heat transfer. Dry foods have sufficiently low water to permit storage up to several months after grinding without substantial changes in nutritional value, taste, or microbial safety (Fellows, 2009).

Industrial waste and mining can be sources of heavy metal pollution in aquatic environments (Gumgum et al., 1994) that can be transferred to marine organisms. Fish and other marine invertebrates are considered as bio-indicators of metal concentrations in aquatic ecosystems (Domingo et al., 2007), because they can concentrate large amounts of metals in their tissues (Y1lmaz et al., 2007). It is important to determine the concentrations of heavy metals in commercial fish in order to evaluate the possible health risks of fish consumption by humans (Yilmaz et al., 2007). The accumulation of heavy metals in human tissues can result in chronic illness and cause potential damage to the population.

Microbial safety is an important indicator of protein qualityand storage tolerance. There are many techniques to reduce
http://dx.doi.org/10.5657/FAS.2014.0059

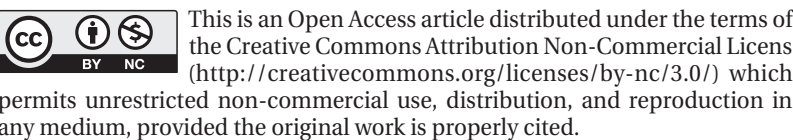

Received 25 November 2013;

Revised 30 December 2013

Accepted 30 December 2013

*Corresponding Author

E-mail: bschun@pknu.ac.kr 
the microbial content of foods. For the past two decades, high-pressure carbon dioxide (HPCD) has been used as a nonthermal pasteurization technique for food (Spilimbergo et al., 2002). In the HPCD technique, food is contacted with supercritical carbon dioxide $\left(\mathrm{SC}-\mathrm{CO}_{2}\right)$ for a certain amount of time in a batch, semi-batch or continuous manner. $\mathrm{SC}-\mathrm{CO}_{2}$ has the ability to diffuse through solids like a gas, and to dissolve materials like a liquid. Additionally, it can readily change density with minor changes in temperature or pressure. The $\mathrm{SC}-\mathrm{CO}_{2}$ technique presents advantages over high hydrostatic pressure (HHP) because of the milder conditions required. In addition to the environmentally benign nature of the $\mathrm{SC}-\mathrm{CO}_{2}$ process ( $\mathrm{CO}_{2}$ is nontoxic), the $\mathrm{CO}_{2}$ pressures applied for preservation are much lower (generally below $10 \mathrm{MPa}$ ) than the hydrostatic pressures employed in HHP (300-600 MPa), making it easier to control pressure in the $\mathrm{SC}-\mathrm{CO}_{2}$ technique (Spilimbergo et al., 2002). Alcohol also has as antimicrobial properties. The bactericidal activity of alcohol is due to several factors: disruption of membrane structure or function (Fried and Novick, 1973; Halegoua and Inouye, 1979; Barker and Park, 2001; Silveira et al., 2004); interference with cell division, affects on steady-state growth (Fried and Novick, 1973); variations in fatty acid composition and protein synthesis (Chiou et al., 2004); inhibition of nutrient transport via membrane-bound ATPases (Bowles and Ellefson, 1985); alteration of membrane pH (Bowles and Ellefson, 1985; Terracciano and Kashket, 1986) and membrane potential (Terracciano and Kashket, 1986); and a decrease in intracellular $\mathrm{pH}$ (Bowles and Ellefson, 1985; Huang et al., 1986; Terracciano and Kashket, 1986).

Refrigeration preserves food by slowing down the growth and reproduction of microorganisms and the action of enzymes that cause food to rot. Freezing is one of the most commonly used processes for preserving a wide range of foods, including prepared foods that would not have required freezing in their unprepared state.

The goal of this study was to determine the effectiveness of size reduction using various mesh sizes and to determine the solubility of mackerel muscle that has been freeze-dried, deoiled by $\mathrm{SC}-\mathrm{CO}_{2}$, or roasted. In addition, we measure the concentrations of heavy metals and the inhibition of microbial growth under storage at different temperatures of $\mathrm{SC}-\mathrm{CO}_{2}^{-}$, hexane-, and ethanol-treated mackerel muscle to determine safety profiles.

\section{Materials and Methods}

\section{Materials}

Washed mackerel muscle samples were collected from F \& F Co., Busan, Korea and transported to the laboratory on ice. Carbon dioxide $\left(\mathrm{CO}_{2}, 99 \%\right.$ pure $)$ was supplied by KOSEM,
Korea. All other reagents used in this study were of analytical or high performance liquid chromatography (HPLC) grade.

\section{Sample preparation}

Raw mackerel muscle samples were freeze dried (EYELA FDV-2100 freeze dryer, Rikakikai Co. Ltd., Tokyo, Japan) for approximately $72 \mathrm{~h}$. Dried samples was then crushed in a mechanical blender and stored at $-20^{\circ} \mathrm{C}$ for until analysis.

\section{Supercritical carbon dioxide $\left(\mathrm{SC}-\mathrm{CO}_{2}\right)$ treatment}

We used a small-scale of supercritical carbon dioxide extraction unit $d$ to remove oil from freeze-dried mackerel muscle. This apparatus could be operated at pressures up to 700 bar. We placed $600 \mathrm{~g}$ freeze-dried mackerel muscle into the stainless steel extraction vessel tightly sealed it with a stainless steel cap. $\mathrm{CO}_{2}$ was then pumped at constant pressure through the extractor unit into the extraction vessel up to the desired pressure. A back-pressure regulator was used to control the $\mathrm{CO}_{2}$ pressure. The extraction temperature was maintained by a water bath connected to the extraction vessel. The experiment was carried out at $55^{\circ} \mathrm{C}$ and 400 bar for $2 \mathrm{~h}$ to completely remove oil from the muscle. Finally, the remaining oil-free muscle residues (deoiled residues) were again crushed in a mechanical blender and stored at $-20^{\circ} \mathrm{C}$ for further analysis.

\section{Solvent treatment}

We used hexane and ethanol to remove oil from freezedried crushed mackerel muscle. We placed250 g mussle tissue in a beaker with $1,250 \mathrm{~mL}$ of either hexane or ethanol and stirred at $300 \mathrm{rpm}$ using a magnetic stirrer for $24 \mathrm{~h}$ at $45^{\circ} \mathrm{C}$. After extraction, the solvent was separated by filtration, and the remaining residues were dried at $40^{\circ} \mathrm{C}$ for $2 \mathrm{~h}$. The lipidfree residues were then collected, crushed again in a mechanical blender and stored at $-20^{\circ} \mathrm{C}$ until further use and analysis.

\section{Roasting treatment}

We roasted $200 \mathrm{~g}$ freeze-dried crushed mackerel muscle in an $80^{\circ} \mathrm{C}$ oven for $6 \mathrm{~h}$. The sample was then cooled at room temperature, crushed in a mechanical blender, and stored at $-20^{\circ} \mathrm{C}$ for further analysis.

\section{Size reduction}

Freeze-dried mackerel muscle, roasted muscle, and solvent- or $\mathrm{SC}-\mathrm{CO}_{2}$-deoiled muscle were sieved through mesh sizes of $300 \mu \mathrm{m}, 500 \mu \mathrm{m}, 710 \mu \mathrm{m}$ and $1,000 \mu \mathrm{m}$, respectively. Sieve and percent mass retention were calculated according to the modified method of Fellows (2009). 


\section{Determination of percent solubility}

We mixed $2 \mathrm{~g}$ of each sieved sample from freeze-dried, roasted or deoiled mackerel muscle with water, hexane, or ethanol at a 1:10 ratio and stirred at $400 \mathrm{rpm}$ for $1 \mathrm{~h}$ at room temperature. The solutions were then separated by filtration, and the remaining residues were dried and weighed. The percent solubility was determined as:

$$
\begin{aligned}
\text { Solubility }(\%)= & (\text { weight of initial sample }- \\
& \text { weight of residues after reaction }) \times 100
\end{aligned}
$$

\section{Measurement of heavy metal contents}

Metals contents were measured in mackerel muscle (sieved at $710 \mu \mathrm{m}$ ) of each treatment according to the method of Ackacha et al. (2010) with some modifications. We dissolved $1 \mathrm{~g}$ of each sample in $10 \mathrm{~mL}$ nitric acid, and heated it at $130^{\circ} \mathrm{C}$ for 5 min until it was fully dissolved, and filtered the sample. We then transferred the sample to a $100 \mathrm{~mL}$ volumetric flask filled with de-ionized water. We used inductively coupled plasma mass spectrometry (ICP-MS; Elan 6100, Perkin-Elmer, USA) to measure the concentrations of arsenic (As), cadmium (Cd), lead $(\mathrm{Pb})$, iron $(\mathrm{Fe})$ and zinc $(\mathrm{Zn})$, and we used an inductively coupled plasma optical emission spectrometer (ICP-OES; Optima 7300DV, Perkin-Elmer, USA) to measure mercury (Hg).

\section{Microbial safety analysis}

We counted the number of microbial colonies in the different treatment samples of mackerel muscle $(710 \mu \mathrm{m}$ sieve size) using the plate count method (Gilbert et al., 2000; Cappuccino and Sherman, 2002). We mixed $1 \mathrm{~g}$ of sample with 5 $\mathrm{mL} 0.85 \% \mathrm{NaCl}$ solution (saline) and vortexed for $2 \mathrm{~min}$ to dissolve. We then filtered the solution through filter paper and diluted in saline at dilutions of $10^{-1}, 10^{-2}, 10^{-3}$, or $10^{-4}$. We used nutrient agar (Merck KGaA, Darmstadr, Germany) that was sterilized at $121^{\circ} \mathrm{C}$ for $15 \mathrm{~min}$ as growth medium for bacterial strains. We then poured the agar into sterile glass petri dishes and allowed to set. We inoculated the plates with $1 \mathrm{~mL}$ of diluted samples and incubated at $37^{\circ} \mathrm{C}$ for $24 \mathrm{~h}$, after which we counted the number of bacterial colony-forming units (CFU) and estimated the total bacterial concentration as $\log (\mathrm{CFU} /$ $\mathrm{mL})$.

\section{Statistical analysis}

All experiments were carried out in triplicate. Data are expressed as the means \pm standard deviation (SD). Significant differences $(P<0.05)$ between means were identified by descriptive statistics using SPSS version 15.0 (SPSS, Inc., Chicago, IL, USA).

\section{Results and Discussion}

\section{Size reduction}

The residue size of mackerel muscle became smaller after removing oil using $\mathrm{SC}-\mathrm{CO}_{2}$ (Table 1). The sieve percentages for de-oiled muscle residues sieved at $1,000 \mu \mathrm{m}$ and $300 \mu \mathrm{m}$ mesh were determined to be $90.43 \%$ and $80.19 \%$, respectively, which were higher than those values for freeze-dried mackerel muscle $(61.19 \%$ and $22.70 \%)$ and roasted mackerel (75.08\% and 24.94\%) using the same mesh sizes (Table 1). This is because after removing the oil, the residues were less sticky, allowing greater ability to pass through the sieve. The low sieve percentages for roasted mackerel muscle compared with freeze-dried mackerel muscle may be because the roasted residues were thoroughly dried by the heat treatment.

\section{Solubility percentage}

The solubility percentage of freeze-dried, $\mathrm{SC}-\mathrm{CO}_{2}$ extracted, and roasted mackerel muscle samples varied for different size residues and after sieving with different solvents (Table 2 ). The highest solubility value for deoiled mackerel (41.25\%) was found when the muscle was sieved in water through a $300 \mu \mathrm{m}$ sieve. Due to oil separation, the solubility of tissue residues was higher in water. In contrast, the highest solubility value for roasted mackerel muscle were found when using hexane $(30.50 \%)$ and ethanol $(40.00 \%)$ with a $300 \mu \mathrm{m}$ sieve size. Therefore, the solubility of deoiled residues was higher in water, and non-deoiled residues were more soluble in organic solvents.

\section{Heavy metal content}

Maximum permitted level of some heavy metals in fish enforced by Australia and Singapore showed in Table 3. Lead

Table 1. Sieve percentage determination of differently treated mackerel muscle residues using various mesh size

\begin{tabular}{lrrc}
\hline Sample name & $\begin{array}{c}\text { Mesh size } \\
(\boldsymbol{\mu m})\end{array}$ & $\begin{array}{c}\text { Mass retain } \\
(\mathbf{\%})\end{array}$ & $\begin{array}{c}\text { Sieve } \\
(\mathbf{\%})\end{array}$ \\
\hline Freeze dried & 1000 & $38.81 \pm 1.25$ & $61.19 \pm 1.72$ \\
mackerel muscle & 710 & $48.76 \pm 1.36$ & $51.24 \pm 1.40$ \\
& 500 & $65.91 \pm 1.28$ & $34.09 \pm 1.28$ \\
& 300 & $77.30 \pm 1.45$ & $22.70 \pm 1.15$ \\
Residues after & 1000 & $9.57 \pm 0.75$ & $90.43 \pm 2.05$ \\
$\mathrm{SC}^{-\mathrm{CO}_{2} \text { extraction }}$ & 710 & $12.93 \pm 0.80$ & $87.07 \pm 1.85$ \\
& 500 & $17.73 \pm 0.93$ & $82.27 \pm 1.78$ \\
& 300 & $19.81 \pm 1.10$ & $80.19 \pm 1.82$ \\
Roasted mackerel & 1000 & $24.92 \pm 1.20$ & $75.08 \pm 1.76$ \\
muscle & 710 & $38.00 \pm 1.32$ & $62.00 \pm 1.68$ \\
& 500 & $57.52 \pm 1.38$ & $42.48 \pm 1.27$ \\
& 300 & $75.06 \pm 1.52$ & $24.94 \pm 1.16$ \\
\hline
\end{tabular}

Results are the mean value of three replicates \pm SD. 
$(\mathrm{Pb})$ is known to reduce cognitive development and intellectual performance in children and to increase blood pressure and cardiovascular disease in adults (Commission of the European Communities, 2002). The $\mathrm{Pb}$ concentration in freezedried mackerel muscle was $0.61 \mu \mathrm{g} / \mathrm{g}$, and this concentration decreased after treatment (Table 4). The $\mathrm{Pb}$ concentrations of mackerel muscle treated with $\mathrm{SC}-\mathrm{CO}_{2}$, hexane, and ethanol were $0.48,0.43$ and $0.60 \mu \mathrm{g} / \mathrm{g}$, respectively. According to the Australia New Zealand Food Authority (2002) and FAO guidelines (Sivaperumal et al., 2007), the allowable level of $\mathrm{Pb}$ in fish is $0.5 \mu \mathrm{g} / \mathrm{g}$. The $\mathrm{Pb}$ levels in our $\mathrm{SC}-\mathrm{CO}_{2}$ - and hexane-treated muscles were less than these recommended levels. The $\mathrm{Pb}$ concentrations in freeze-dried and ethanol-treated muscle were also lower than the $2 \mu \mathrm{g} / \mathrm{g}$ level recommended by the government of Singapore (1990).

Cadmium $(\mathrm{Cd})$ is toxic to humans and it can accumulate in the body, where it may induce kidney dysfunction, skeletal damage and reproductive deficiencies. The greatest concentration of $\mathrm{Cd}$ was found in freeze-dried mackerel muscle $(0.25$ $\mu \mathrm{g} / \mathrm{g}$ ) and the lowest concentrations in $\mathrm{SC}-\mathrm{CO}_{2}$ - and hexanetreated muscle $(0.02 \mu \mathrm{g} / \mathrm{g})$. According to Nauen (1983) guidelines, the maximum permissible Cd levels are 0.05-5.5 $\mu \mathrm{g} / \mathrm{g}$. The Cd levels in all our muscle samples were within this range.

Arsenic (As) toxicity is not fully understood, but its possible effects include hair loss, dermatitis, diarrhea and other gastrointestinal symptoms, fatigue, headaches, confusion, muscle pains, red and white blood cell problems, neurologic symptoms, and liver and kidney damage. The As concentrations in

Table 2. Solubility percentage determination of differently treated mackerel muscle residues using various solvent

\begin{tabular}{lcccc}
\hline \multirow{2}{*}{ Sample name } & Mesh size $(\boldsymbol{\mu m})$ & \multicolumn{3}{c}{ Solubility (\%) } \\
\cline { 3 - 4 } & & Water & Hexane & Ethanol \\
\hline Freeze dried mackerel muscle & 1000 & $18.70 \pm 0.45$ & $20.90 \pm 0.49$ & $26.20 \pm 0.53$ \\
& 710 & $23.60 \pm 0.52$ & $23.20 \pm 0.53$ & $28.65 \pm 0.55$ \\
& 500 & $28.00 \pm 0.50$ & $26.20 \pm 0.55$ & $32.50 \pm 0.58$ \\
Residues after SC-CO & 300 & $30.80 \pm 0.58$ & $29.80 \pm 0.50$ & $37.50 \pm 0.61$ \\
extraction & 1000 & $25.15 \pm 0.46$ & $10.75 \pm 0.25$ & $17.35 \pm 0.38$ \\
& 710 & $35.55 \pm 0.55$ & $14.75 \pm 0.28$ & $18.25 \pm 0.41$ \\
Roasted mackerel muscle & 500 & $37.00 \pm 0.57$ & $15.00 \pm 0.32$ & $19.55 \pm 0.45$ \\
& 300 & $41.25 \pm 0.60$ & $15.85 \pm 0.35$ & $20.75 \pm 0.48$ \\
& 1000 & $20.80 \pm 0.42$ & $23.00 \pm 0.42$ & $27.00 \pm 0.52$ \\
& 710 & $26.80 \pm 0.44$ & $27.20 \pm 0.45$ & $30.80 \pm 0.57$ \\
& 500 & $28.80 \pm 0.48$ & $29.30 \pm 0.39$ & $34.00 \pm 0.61$ \\
\end{tabular}

Data are the mean value of three replicates \pm SD.

Table 3. Maximum permitted level of some heavy metals in fish enforced by Australia and Singapore

\begin{tabular}{lcccl}
\hline Country & $\begin{array}{c}\text { Lead }(\mathbf{P b}) \\
(\boldsymbol{\mu g} / \mathbf{g})\end{array}$ & $\begin{array}{c}\text { Arsenic }(\mathbf{A s}) \\
(\boldsymbol{\mu g} / \mathbf{g})\end{array}$ & $\begin{array}{c}\text { Mercury }(\mathbf{H g}) \\
(\boldsymbol{\mu g} / \mathbf{g})\end{array}$ & \multicolumn{1}{c}{ References } \\
\hline Australia & 0.5 & 2.0 & 0.5 & Australia New Zealand Food Authority (2002) \\
Singapore & 2.0 & 1.0 & 0.5 & Government of Singapore (1990) \\
\hline
\end{tabular}

FSA, Food Standards Australia; FRS, Food Regulations Singapore

Table 4. Heavy metals content of differently treated mackerel muscle residues

\begin{tabular}{lcccccc}
\hline \multirow{2}{*}{ Sample name } & \multicolumn{5}{c}{ Heavy metals } \\
\cline { 2 - 7 } & $\mathbf{P b}(\boldsymbol{\mu g} / \mathbf{g})$ & $\mathbf{C d}(\boldsymbol{\mu g} / \mathbf{g})$ & $\mathbf{A s}(\boldsymbol{\mu g} / \mathbf{g})$ & $\mathbf{H g}(\boldsymbol{\mu g} / \mathbf{g})$ & $\mathbf{F e}(\boldsymbol{\mu g} / \mathbf{g})$ & $\mathbf{Z n}(\boldsymbol{\mu g} / \mathbf{g})$ \\
\hline Freeze dried mackerel muscle & $0.61 \pm 0.07$ & $0.25 \pm 0.03$ & $8.41 \pm 0.15$ & $1.02 \pm 0.09$ & $50.80 \pm 1.25$ & $35.15 \pm 1.10$ \\
Residues after $\mathrm{SC}^{-} \mathrm{CO}_{2}$ extraction & $0.48 \pm 0.05$ & $0.02 \pm 0.005$ & $7.01 \pm 0.12$ & $1.36 \pm 0.12$ & $44.20 \pm 1.20$ & $28.56 \pm 1.23$ \\
Residues after hexane extraction & $0.43 \pm 0.03$ & $0.02 \pm 0.004$ & $5.55 \pm 0.10$ & $1.96 \pm 0.18$ & $49.60 \pm 1.27$ & $24.30 \pm 1.15$ \\
Residues after ethanol extraction & $0.60 \pm 0.08$ & $0.03 \pm 0.002$ & $5.31 \pm 0.11$ & $0.72 \pm 0.06$ & $48.80 \pm 1.22$ & $30.69 \pm 1.24$ \\
\hline
\end{tabular}

Data are the mean value of three replicates \pm SD. 
mackerel muscle that was freeze-dried or $\mathrm{SC}-\mathrm{CO}_{2}^{-}$, hexane, or ethanol-treated were $8.41,7.01,5.50$ and $5.31 \mu \mathrm{g} / \mathrm{g}$, respectively. The As concentration on treated and non-treated mackerel muscle was much higher than the permissible limits set by the Australia New Zealand Food Authority $(2.0 \mu \mathrm{g} / \mathrm{g}$; 2002) and the government of Singapore $(1.0 \mu \mathrm{g} / \mathrm{g} ; 1990)$.

According to the guidelines of the FAO/WHO (1972), the Australia New Zealand Food Authority (2002) and the Singapore government (1990), the permissible mercury (Hg) concentration in fish is $0.5 \mu \mathrm{g} / \mathrm{g}$ but our freeze-dried and $\mathrm{SC}-\mathrm{CO}_{2}^{-}$, hexane- and ethanol-treated mackerel muscle samples had $\mathrm{Hg}$ concentrations of $1.02,1.36,1.96$ and $0.72 \mu \mathrm{g} / \mathrm{g}$, respectively, which were higher than the acceptable levels. The FAO/WHO (1972) also reported acceptable Hg values for swordfish, tuna, and halibut as $0.20-1.51 \mu \mathrm{g} / \mathrm{g}$.

Zinc $(\mathrm{Zn})$ is involved in most metabolic pathways in humans. It is widespread in living organisms due to its biological significance. $\mathrm{Zn}$ deficiency can lead to loss of appetite, growth retardation, skin changes and immunological abnormalities (Malakootian et al., 2011). According to the Food Codex (Maff, 1995), the permissible Zn level for fish is $50 \mu \mathrm{g} / \mathrm{g}$. The highest $\mathrm{Zn}$ concentration in freeze-dried mackerel muscle was $35.15 \mu \mathrm{g} / \mathrm{g}$ and this concentration decreased slightly after treatment. The United States Environmental Protection Agency (US-EPA) and the European Commission (EC) have not set any standards or limits for zinc concentrations (Alimentarius, 1994; Ashraf, 2006).

Iron $(\mathrm{Fe})$ concentrations in freeze-dried, $\mathrm{SC}-\mathrm{CO}_{2^{-}}$, hexane- and ethanol-treated mackerel muscle were 50.80, 44.20, 49.60 and $48.80 \mu \mathrm{g} / \mathrm{g}$, respectively. We found no reports on the maximum safe levels of Fe in fish tissues. Turkmen et al. (2006) reported that Fe concentrations in fish muscle ranged from $8.87-18.80 \mu \mathrm{g} / \mathrm{g}$, respectively. Essential metals, such as $\mathrm{Fe}$ and $\mathrm{Zn}$, showed higher concentrations in mackerel muscle, presumably due to their function as co-factors for enzyme activation that causes tight regulation of their homeostatic levels in fish (Yilmaz, 2009).

\section{Microbial safety}

We found changes in bacterial plate counts in freeze-dried, $\mathrm{SC}-\mathrm{CO}_{2}-$, hexane and ethanol-treated muscle after storage for six months at $-20^{\circ} \mathrm{C}, 5^{\circ} \mathrm{C}$ and $25^{\circ} \mathrm{C}$ (Figs. 1-3). During storage at $-20^{\circ} \mathrm{C}$, freeze-dried mackerel muscle showed bacterial colonies of $1.90 \log \mathrm{CFU} / \mathrm{mL}$, and there were no drastic changes after 6 months. However, SC- $\mathrm{CO}_{2}$ - and ethanol-treated mackerel muscle showed no bacterial colonies for up to 4 months and very few colonies after 5 or 6 months of storage, bacterial colonies in freeze-dried mackerel muscle were 2.18 and $2.54 \log (\mathrm{CFU} / \mathrm{mL})$ at $5^{\circ} \mathrm{C}$ and $25^{\circ} \mathrm{C}$, respectively, which were higher than the number of colonies at $-20^{\circ} \mathrm{C}(2.08 \log (\mathrm{CFU} /$ $\mathrm{mL})$ ). Microbial growth was very slow after treating the mackerel muscle under different storage conditions, compared with freeze-dried mackerel muscle. Among the treated

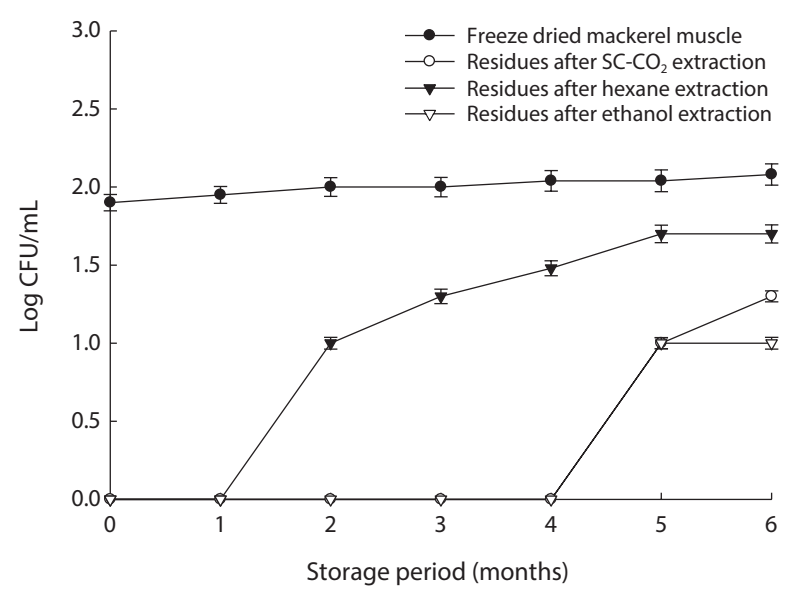

Fig. 1. Changes of total bacterial counts during storage period at $-20^{\circ} \mathrm{C}$ of differently treated mackerel muscle residues. Data are the mean value of three replicates \pm SD.

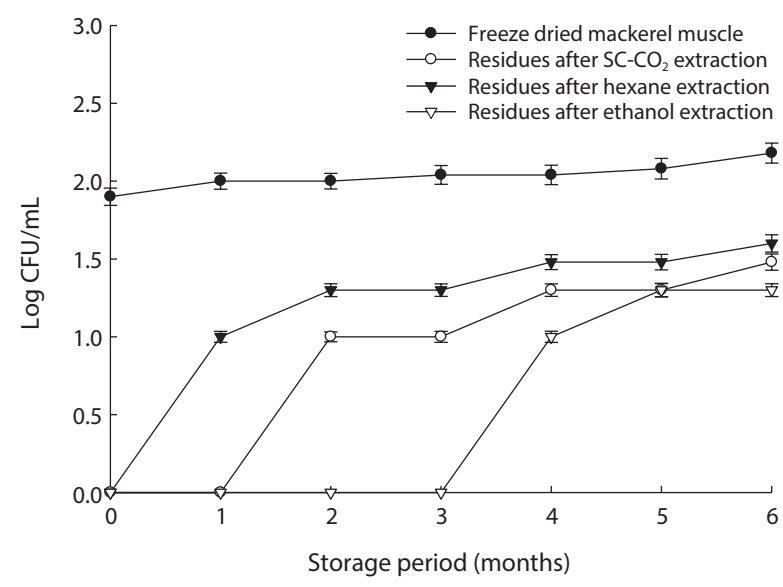

Fig. 2. Changes of total bacterial counts during storage period at $5^{\circ} \mathrm{C}$ of differently treated mackerel muscle residues. Data are the mean value of three replicates \pm SD.

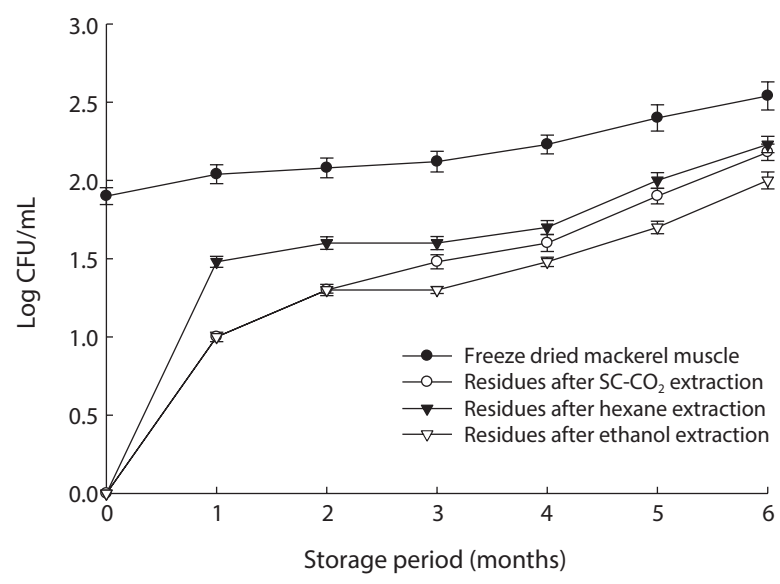

Fig. 3. Changes of total bacterial counts during storage period at $25^{\circ} \mathrm{C}$ of differently treated mackerel muscle residues. Data are the mean value of three replicates $\pm S D$. 
mackerel muscle samples, bacterial colonies were very low in those treated with $\mathrm{SC}-\mathrm{CO}_{2}$ and ethanol. Lin et al. (1992a, 1993) reported that $\mathrm{SC}-\mathrm{CO}_{2}$ penetrates cells and accumulates to a critical density, after which it removes intracellular constituents, such as phospholipids and hydrophobic compounds, which disturb or alter the structure of the biomembrane and balance in the biological system, thus promoting microbial inactivation. Many authors have reported that ethanol has microbial inactivating properties (Dabbah et al., 1970; Smith et al., 1987; Smith et al., 1994; Corcuff et al., 1996; Daifas et al., 2000). Therefore, $\mathrm{SC}-\mathrm{CO}_{2}$ - and ethanol-treated mackerel muscle are good methods for long term storage.

\section{Acknowledgements}

This work (Grants No. C0019011) was supported by Business for Academic-industrial Cooperative establishments funded Korea Small and Medium Business Administration in 2012

\section{References}

Ackacha MA, Khalifa KM, Hamil AM and Al-Houni AQA. 2010. Determination of heavy metals in fish species of the Mediterranean sea (Libyan coast line) using atomic absorption spectrometry. J Chem Tech Res 2, 1350-1354.

Alimentarius C. 1994. Joint FAO/WHO food standards programme. Codex committee on methods of analysis and sampling. 19th session. Criteria for evaluating acceptable methods for codex purposes, Budapest, Hungary.

Ashraf W. 2006. Levels of selected heavy metals in tuna fish. Arab J Sci Eng 31, 89-92.

Australia New Zealand Food Authority. 2002. Food. Standards Code Part 1.4-Contaminants and Residues.

Barker C and Park SF. 2001. Sensitization of Listeria monocytogenes to low $\mathrm{pH}$, organic acids, and osmotic stress by ethanol. J Appl Environ Microbiol 67, 1594-1600.

Bowles LK and Ellefson WL. 1985. Effects of butanol on Clostridium acetobutylicum. J Appl Environ Microbiol 50, 1165-1170.

Cappuccino JG and Sherman N. 2002. Microbiology: A laboratory manual. 6th ed. Dorling kindersley private limited, India. pp. 493-494.

Chiou RY, Phillips RD, Zhao P, Doyle MP and Beuchat LR. 2004. Ethanol-mediated variations in cellular fatty acid composition and protein profiles of two genotypically different strains of Escherichia coli O157:H7. J Appl Environ Microbiol 70, 2204-2210.

Commission of the European Communities. 2002. Commission regulation (EC) No. 221/ 2002 of 6 February 2002 amending regulation (EC) No. 466/2002 setting maximum levels for certain contaminants in food stuffs. Off J Eur Commun Brussels, 6 February 2002.

Corcuff R, Arul J, Hamza F, Castaigne F and Makhlouf J. 1996. Storage of broccoli florets in ethanol vapour-enriched atmosphere. J Postharv Biol Technol 7, 219-229.
Dabbah R, Edwards VM and Moats WA. 1970. Antimicrobial action of some citrus fruits oils on selected food-borne bacteria. J Appl Microbiol 19, 27-31.

Daifas DP, Smith JP and Tarte I. 2000. Effect of ethanol vapour on growth and toxin production by Clostridium botulinum in a high moisture bakery product. J Food Safety 20, 111-125.

Domingo JL, Bocio A, Marti-Cid R and Llobt JM. 2007. Benefits and risks of fishconsumption Part II. RIBEPEIX, a computer program to optimize the balance between the intake of Omega-3 fatty acids and chemical contaminants. J Toxicol 230, 227-233.

FAO/WHO. 1972. Evaluation of certain food additives and the contaminants mercury, cadmium and lead. WHO technical report series No. 505. Food and Agriculture/World Health Organisation, Geneva.

Fellows PJ. 2009. Food processing technology: principles and practice. 3rd ed. Woodhead publishing limited, New Delhi, India.

Fried VA and Novick A. 1973. Organic solvents as probes for the structure and function of the bacterial membrane: effects of ethanol on the wild type and an ethanol-resistant mutant of Escherichia coli K-12. J Bacteriol 114, 239-248.

Gilbert RJ, Louvois JD, Donovan T, Little C, Nye K, Ribeiro CD, Richards J, Roberts D and Bolton FJ. 2000. Guidelines for the microbiological quality of some ready-to-eat foods sampled at the point of sale. J Commun Dis Public Health 3, 163-167.

Government of Singapore. 1990. Sale of food act (Chapter 283): Food regulations. Singapore national printers limited, Singapore.

Gumgum B, Unlu E, Tez Z and Gulsun N. 1994. Heavy metal pollution in water, sediment and fish from the Tigris River in Turkey. J Chemosphere 290, 111-116.

Halegoua S and Inouye M. 1979. Translocation and assembly of outer membrane proteins of Escherichia coli. Selective accumulation of precursors and novel assembly intermediates caused by phenethyl alcohol. J Mol Biol 130, 39-61.

Huang L, Forsberg CW and Gibbins LN. 1986. Influence of external pH and fermentation products on Clostridium acetobutylicum intracellular $\mathrm{pH}$ and cellular distribution of fermentation products. J Appl Environ Microbiol 51, 1230-1234.

Lin HM, Yang ZY and Chen LF. 1992a. Inactivation of Saccharomyces cerevisiae by supercritical and subcritical carbon dioxide. J Biotechnol Progress 8, 458-461.

Lin HM, Yang ZY and Chen LF. 1993. Inactivation of Leuconostoc dextranicum with carbon dioxide under pressure. Biochem Eng J 52, 29-34.

Malakootian M, Tahergorabi M, Daneshpajooh M and Amirtaheri K. 2011. Determination of

$\mathrm{Pb}, \mathrm{Cd}, \mathrm{Ni}$, and $\mathrm{Zn}$ concentrations in canned fish in southern Iran. Sacha J Environ Studies 1, 94-100.

Ministry of Agriculture, Fisheries and Food. 1995. Monitoring and surveillance of non-radioactive contaminants in the aquatic environment and activities regulating the disposal of waste at sea, 1993. Aquat Environ Monit Rep. No. 44, Directorate of fisheries research, Lowestoft.

Nauen CE. 1983. Compilation of legal limits for hazardous substances in fish and fishery products. Food and Agriculture Organization of 
the united nations, Rome, Italy. pp. 5-100.

Silveira MG, Baumgartner M, Rombouts FM and Abee T. 2004. Effect of adaptation to ethanol on cytoplasmic and membrane protein profiles of Oenococcus oeni. J Appl Environ Microbiol 70, 27482755 .

Sivaperumal P, Sankar TV and Viswanathan Nair PG. 2007. Heavy metal concentrations in fish, shellfish and fish products from internal markets of India vis-a-vis international standards. J Food Chem $102,612-620$

Smith JP, Lyver A and Morris J. 1994. Effect of ethanol vapour on the growth of common mold contaminant of bakery products. J Food Microbiol 11, 329-337.

Smith JP, Ooraikul B, Koersen WJ, Jackson ED and Lawrence RA. 1987. Shelf-life extension of a bakery product using ethanol vapour. J Food Microbiol 4, 329-337.

Spilimbergo S, Elvassore N and Bertucco A. 2002. Microbial inactiva- tion by high-pressure. J Supercrit Fluids 22, 55-63.

Terracciano JS and Kashket ER. 1986. Intracellular conditions required for the initiation of solvent production by Clostridium acetobutylicum. J Appl Environ Microbiol 52, 86-91.

Turkmen AM, Turkmen Y, Tepe Y and Oymael S. 2006. Heavy metal levels in blue crap (Callinectes sapidur) and mullet (Mugil cephalus) in Iskenderun Bay. J Bull Environ Contam Toxicol 77, 186193.

Yilmaz F, Ozdemir N, Demirak A and Tuna A. 2007. Heavy metal levels in two fish species Leuciscus cephalus and Lepomis gibbosus. J Food Chem 100, 830-835.

Yilmaz F. 2009. The comparison of heavy metal concentrations $(\mathrm{Cd}$ $\mathrm{Cu}, \mathrm{Mn}, \mathrm{Pb}$, and $\mathrm{Zn}$ ) in tissues of three economically important fish (Anguilla anguilla, Mugil cephalus and Oreochromis niloticus) inhibiting Koycegiz lake-Mugla. Trk J Sci Technol 4, 7-15. 